\author{
地域在住要支援・要介護高齢者におけるフレイル要因 \\ および身体各部位筋厚の性差の検討
}

\title{
The examinations of sex difference between frailty factor and site-specific muscle thickness in community-dwelling older adults under long-term care.
}

\author{
福尾 実人 ${ }^{1)}$, 村木 里志 ${ }^{2}$ \\ Jitsuhito Fukuo ${ }^{1)}$, Satoshi Muraki ${ }^{2)}$
}

\begin{abstract}
要旨：【目的】本研究では，男女間に㧍けるフレイル要因および身体各部位筋厚の性差を 検討した。【方法】対象は要支援 1 から要介護 2 までの要支援・要介護男女高齢者37名と し，男性高齢者 22 名と女性高齢者15名に分類した。フレイルの評価には基本チェックリス トを用いた。身体 6 部位の筋厚に加え，身長，体重，BMI を測定した。【結果】男性高齢 者では女性高齢者と比べて閉じこもり傾向にあった。各部位筋厚では男性高齢者に比べて 女性高齢者は大腿前部，上腕前部，上腕後部，下腿前部に有意な低值を認めたが，大腿後 部と下腿後部の筋厚には性差を認めなかった。【結論】本研究結果より, 要支援・要介護 高齢者では性差の特徵に応じた介護予防の実践が期待される。
\end{abstract}

キーワード：地域在住要支援・要介護高齢者, フレイル要因, 身体各部位筋厚, 性差

\begin{abstract}
Objective: In this study, we investigated sex differences in frail factors and site -specific muscle thickness.

Methods: The subjects in the study were thirty-seven men and women issued with mild support required 1 to needs nursing care 2 . They were classified into 22 men and 15 women. Kihon checklist was used to evaluate frailty. Muscle thickness of six regions of the body, as well as body height, body weight, body mass index (BMI) were measured.

Results: The tendency to be housebound was higher in men than in women. The muscle thickness of the anterior thigh, anterior upper arm, posterior upper arm, and anterior lower legs were significantly lower in women than in men.

Conclusion: The results of this study revealed that the prevention of frailty while considering the characteristics of sex differences are expected to be practiced.
\end{abstract}

Key word: Community-dwelling older adults under long-term care, Frailty factor, Sitespecific muscle thickness, Sex difference

受付日：2021年 4 月 6 日，採択日：2021年 8 月11日

1) 日立造船健康保険組合 因島総合病院リハビリテーション部 テ722-2323 広島県尾道市因島土生町2561番地

Department of Rehabilitation, Innoshima General Hospital

E-mail :fxsfs838@gmail.com

2) 九州大学大学院芸術工学研究院

Graduate School of Design, Kyushu University 


\section{I 、はじめに}

わが国は諸外国に例をみないスピードで人口高齢化 が進んで㧍り，2065年には3.9人に 1 人が75歳以上の 後期高齢者となる ${ }^{10}$ 。高齢になると心身の機能の減衰 が原因となるフレイルの割合が高くなる2)。65歳以上 の日本人高齢者に打けるフレイルの有症率を示したシ ステマティックレビューによる報告では男性7.6\%, 女性 $8.1 \%$ ，男女全体では7.4\%となるが，加齢ととも にその割合は女性に高くなり ${ }^{3)}$, 特に高齢期において はフレイルの有症率に性差が認められることが推察さ れる。また，フレイルは筋量の減少により進行が速ま り")，その中核要因としてサルコペニアが梁く関係し ていることが示されている5)。さらに，高齢期におけ るフレイルでは身体的側面に加えて精神・心理的扮よ び社会的な側面の問題()により活動量が低下し，遂に は筋量が減少するサルコペニアにまで至るサイクルを 形成する7。以上のことから, フレイルそして要介護 化を効果的に予防するためには, 筋量低下の問題とフ レイルの 3 側面（身体的, 精神 - 心理的, 社会的）の 両面を評価する必要がある。

地域在住高齢者を対象とした筋厚の測定には小型で 持ち運びやすく, 多様なフィールドで評価できる超音 波診断装置を用いている8)。この超音波診断装置は, 高齢者の筋厚の測定において信頼性と妥当性が報告さ れている9)。また, Miyatani ら ${ }^{10)}$ は上腕, 大腿, 下腿 の各部位の筋厚とそれらの部位の筋横断面積が強い正 の相関を認めると報告しており，各部位の筋厚では筋 量の大小の指標となることが示唆されている。これら のことから，筋厚の測定はサルコペニアおよびフレイ ルを早期に発見できる有用な測定方法であると考えら れる。

これまで，50歳以上の地域在住中高齢者を対象とし たAbe ら ${ }^{11}$ の研究によると, 男女間では大腿前部に 加えて大腿後部の筋厚に有意な差を認めており，その 他の上腕前 - 後部, 肩甲骨下部, 腹部, 下腿前 - 後部 の筋厚においても男性は女性よりも高值を示してい る ${ }^{12)}$ 。一方, 入院をしている40歳以上の日本人肥満中 高齢患者を対象としたIdo ら ${ }^{13)}$ の研究においては, 男 女間の四肢抢よび全身の筋量は男性で高值を示してい るが，身体各部位筋厚では上腕後部および大腿前・後 部で有意な差は認められていない。これらのことから， 健常な地域在住中高齢者と前述 ${ }^{13)}$ のような入院中の中 高齢者では身体各部位筋厚の性差は異なることが示唆 される。しかしながら，これまでの報告11,12)では高齢
期の対象者抒よび入院患者の身体各部位筋厚の性差を 調査した報告は散見されているが，地域在住要支援・ 要介護高齢者の身体的および精神・心理的，社会的な 3 側面を含んだフレイル要因と身体各部位筋厚の性差 を調査した報告はみられない。

そこで，本研究では男性高齢者と女性高齢者の間に おいてフレイルの 3 側面の問題および身体各部位の筋 厚に性差が生じるという仮説に基づき, 地域在住要支 援・要介護高齢者に打けるフレイルの 3 側面と身体各 部位筋厚の性差を検討することを目的とした。

\section{II. 対象と方法}

\section{1. 対 象}

対象は要支援 1 から要介護 2 までの要支援・要介護 の男女高齢者37名とし，その性別の内訳は65. 6 86.6 歳の男性要支援・要介護高齢者 (男性高齢者) 22 名 (平 均年齢土標準偏差：76.6 5 5.7歳)，62.9 89. 1歳の女 性要支援・要介護高齢者（女性高齢者）15名（平均年 齢土標準偏差：79.8 0 8. 歳）とした。

対象者の除外基準は, 杖や歩行補助具の有無に関わ らず歩行に介助を必要とする者, 最近 6 か月以内に脳 卒中などの神経系疾患や整形外科疾患を起こした者, 認知症により意思疎通が困難な者とした。ただし，本 研究の要支援・要介護高齢者群は通所サービスおよび 訪問リハビリテーション（訪問リハビリ）を利用して いるため, そこでの週 1 回以上の30分から 1 時間程度 のリハビリテーション（リハビリ）をしている者が含 まれている。

すべての対象者には, 事前に研究の趣旨と目的を十 分に説明し，書面により研究参加への同意を得た。研 究の参加は自由意志であること, 調査に協力しないこ とや途中で中止した場合であっても対象者には不利益 を生じることがないこと，測定中後においても同意を 撤回できることを説明した。本研究は, 九州大学大学 院芸術工学研究院の実験倫理委員会の承認（番号： 234）を受けて実施した。

\section{2. 方 法 \\ 2 - 1 身体計測}

各対象者の身長および体重を測定し，得られた測定 值から Body Mass Index [BMI : 体重 $(\mathrm{kg})$ ／身長 $\left.(\mathrm{m})^{2}\right]$ を求めた。 


\section{2 - 2 フレイルの評価}

フレイルの評価には, 厚生労働省が示している基本 チェックリストを用いた ${ }^{14)}$ 。この基本チェックリスト の下位項目はフレイルの身体的, 精神・心理的および 社会的な 3 つの側面を総合的に評価することが示唆さ れている15)。

\section{$2-3$ 身体各部位筋厚の計測}

身体各部位の筋厚の指標としては超音波 $\mathrm{B}$ モード装 置(SSA-640A Viamo, TOSHIBA) を用いて, 上腕前・ 後部, 大腿前・後部, 下腿前・後部を測定した。測定 部位の解剖学的位置は, 安部ら ${ }^{16)}$ が報告しているもの と同一とした（表 1 )。対象者はマットレスもしくは ベッド上にて安静臥位姿勢となり，解剖学的肢位にな るよう姿勢を調節した。筋厚の測定部位は利き手側ま たは健常側とした。はじめに，身体前面の部位（上腕 前部, 大腿前部, 下腿前部）を仰臥位安静姿勢にて測 定を行った。次に，身体後面の部位（上腕後部，大腿 後部, 下腿後部）を腹臥位安静姿勢にて測定した。測 定中，対象者には撮影する筋に力を入れないよう指示 した。超音波プローブには超音波用ゼリーを塗布し, 対象者の筋組織を圧迫しないよう皮膚表面上に接触さ せた。超音波プローブは短軸方向に走査して筋肉の横 断面を撮影した。各横断面画像は皮下脂肪組織と筋組 織との境界から筋組織と骨組織との境界までの長さを 計測し, その值を各部位における筋厚とした。その測 定は，超音波診断装置による筋厚の評価方法に習熟し た著者が各部位 1 回ずつ行い, その測定した值を代表 值（mm）として用いた。なお，本研究では女性高齢 者は男性高齢者と比べて体型（身長・体重）が大きく 異なるため, 男女別に筋厚と身長および体重の相関関 係を分析した。その結果，各部位の筋厚と体重は上腕 前部（男性 $r=0.695$, 女性 $r=0.599)$ および後部 (男性 $r=0.585$, 女性 $r=0.641$ ), 大腿前部（男 性 $r=0.810$, 女性 $r=0.625)$ および後部（男性 $r=0.484$, 女性 $r=0.613$ ), 下腿前部（男性 $r=$
0.584）に有意な正の相関を認めた。一方，各部位の 筋厚と身長に有意な相関関係は認められなかった。そ のため, 本研究では形態上の違いによる影響を除外す るため，筋厚 $(\mathrm{mm})$ を体重の $1 / 3$ 乗 $\left(\right.$ 体重 $\left.{ }^{1 / 3}\right)$ で 除した数值を筋厚補正值として用いた ${ }^{17)}$ 。算出式は下 式の通りである。

筋厚補正值 $\left(\mathrm{mm} / \mathrm{kg}^{1 / 3}\right)$ =筋厚 $(\mathrm{mm}) /$ 体重 ${ }^{1 / 3}$

\section{$2-4$ 統計処理}

各測定項目の正規性を Shapiro-Wilk 検定にて確認 した。男性高齢者群と女性高齢者群による 2 群間の比 較には，対応のないt検定または Mann-Whitney のU 検定を用いた。また，2 群間の要介護度別の人数(\%) は名義尺度として検定した後，すべての項目において セルの期待度数は 5 未満であったためFisherの正確 確率検定を用いた。有意水準は $5 \%$ とした。統計ソフ トは，IBM 社 SPSS ver 23.0 for Windows を用いた。

\section{III. 結 果}

身体的特性および要介護度，基本チェックリスト総 合点および下位項目の 2 群間の比較を表 2 に示す。基 本チェックリストの下位項目をそれぞれ 2 群間で比較 した結果，男性高齢者は女性高齢者よりも閉じこもり の得点のみ有意に高值を示したが, その他の下位項目 の得点では有意な差は認められなかった。

身体各部位の筋厚 (mm) および筋厚補正值 $(\mathrm{mm} /$ $\left.\mathrm{kg}^{1 / 3}\right)$ の 2 群間の比較を表 3 に示す。男性高齢者群に 比べて女性高齢者群では上腕前部および後部，大腿前 部，下腿前部の筋厚および筋厚補正值に有意な低值を 認めた。それらの筋厚補正值は大腿前部, 上腕前部, 上腕後部，下腿前部の順に性差が大きかった。一方， 大腿後部と下腿後部に有意な差は認められなかった。

\section{IV. 考 察}

男性高齢者群では女性高齢者群に比べて下位項目の 閉じこもりのみ有意な高值を認めた。健常な地域在住

表 1 ．身体各部位筋厚の解剖学的位置および測定筋

\begin{tabular}{|c|c|c|c|}
\hline 測定 & 部位 & 解剖学的位置 & 測定筋 \\
\hline 上腕 & $\begin{array}{l}\text { 前部 } \\
\text { 後部 }\end{array}$ & 肩峰突起から上腕骨外側上顆の遠位 $60 \%$ & $\begin{array}{l}\text { 上腕二頭筋, 上腕筋 } \\
\text { 上腕三頭筋 }\end{array}$ \\
\hline 大腿 & $\begin{array}{l}\text { 前部 } \\
\text { 後部 }\end{array}$ & 大転子から大腿骨外側顆の中間 & $\begin{array}{l}\text { 大腿四頭筋 } \\
\text { 半膜様筋, 大内転筋 }\end{array}$ \\
\hline 下腿 & $\begin{array}{l}\text { 前部 } \\
\text { 後部 }\end{array}$ & 脛骨外側顆から腓骨外果の遠位30\% & $\begin{array}{l}\text { 前脛骨筋 } \\
\text { 腓腹笳, ヒラメ筋 }\end{array}$ \\
\hline
\end{tabular}


表 2. 要介護男性高齢者群と要介護女性高齢者群における各測定項目の群間比較 $(\mathrm{n}=37)$

\begin{tabular}{|c|c|c|c|c|}
\hline 分類 & 項目 & $\begin{array}{c}\text { 男性高齢者 } \\
(\mathrm{n}=22)\end{array}$ & $\begin{array}{c}\text { 女性高齢者 } \\
(\mathrm{n}=15)\end{array}$ & $\begin{array}{c}\text { 有意確率 } \\
(p \text { 值 })\end{array}$ \\
\hline \multirow{4}{*}{ 身体的特性 } & 年齢（歳） & $76.6 \pm 5.7$ & $79.8 \pm 8.6$ & 0.101 \\
\hline & 身長（cm） & $162.9 \pm 3.6$ & $148.8 \pm 6.8$ & $<0.000$ \\
\hline & 体重（kg） & $63.4 \pm 9.1$ & $48.0 \pm 9.7$ & $<0.000$ \\
\hline & $\operatorname{BMI}\left(\mathrm{kg} / \mathrm{m}^{2}\right)$ & $23.9 \pm 3.6$ & $21.6 \pm 3.8$ & 0.068 \\
\hline \multirow{4}{*}{ 要介護度 } & 要支援 1 （\%） & $5 \quad(22.7)$ & $4 \quad(26.7)$ & 0.541 \\
\hline & 要支援 2（\%） & $6 \quad(27.3)$ & $6 \quad(40)$ & 0.323 \\
\hline & 要介護 1 （\%） & $3(13.6)$ & $1 \quad(6.7)$ & 0.461 \\
\hline & 要介護 2 （\%） & $8 \quad(36.4)$ & $4 \quad(26.7)$ & 0.401 \\
\hline \multirow{9}{*}{$\begin{array}{c}\text { フレイル } \\
\text { 基本チェックリスト }\end{array}$} & 総合点（点） & $10.5 \pm 3.6$ & $11.4 \pm 3.8$ & 0.803 \\
\hline & 手段的生活活動：No. $1 \sim 3$ (点) & $1.9 \pm 1.3$ & $2.1 \pm 0.9$ & 0.724 \\
\hline & 社会的生活活動：No. 4 5 (点) & $0.9 \pm 0.6$ & $0.7 \pm 0.6$ & 0.547 \\
\hline & 身体機能：No. $6 \sim 10$ (点) & $2.8 \pm 1.3$ & $3.3 \pm 1.0$ & 0.242 \\
\hline & 栄養状態：No. 11～12（点） & $0.4 \pm 0.5$ & $0.5 \pm 0.5$ & 0.313 \\
\hline & 口腔機能 : No. 13～15（点） & $1.0 \pm 1.0$ & $1.4 \pm 1.2$ & 0.359 \\
\hline & 閉じこもり：No. 16〜17（点） & $1.0 \pm 0.7$ & $0.5 \pm 0.5$ & $<0.020$ \\
\hline & 認知機能：No. 18～20（点） & $0.8 \pm 1.0$ & $0.9 \pm 0.9$ & 0.383 \\
\hline & 抑うつ気分：No. 21〜25（点） & $1.8 \pm 1.4$ & $1.9 \pm 1.7$ & 0.899 \\
\hline
\end{tabular}

平均值 \pm 標準偏差, 人数 (名, \%)

表 3 . 要介護男性高齢者群と要介護女性高齢者群における身体各部位筋厚の群間比較 $(\mathrm{n}=37)$

\begin{tabular}{clrrc}
\hline 分類 & \multicolumn{1}{c}{ 項目 } & $\begin{array}{c}\text { 男性高齢者 } \\
(\mathrm{n}=22)\end{array}$ & $\begin{array}{c}\text { 女性高齢者 } \\
(\mathrm{n}=15)\end{array}$ & $\begin{array}{c}\text { 有意確率 } \\
(p \text { 值 })\end{array}$ \\
\hline & 上腕前部 $(\mathrm{mm})$ & $27.6 \pm 4.4$ & $19.3 \pm 3.5$ & $<0.000$ \\
& 上腕後部 $(\mathrm{mm})$ & $18.3 \pm 5.9$ & $13.6 \pm 4.1$ & $<0.010$ \\
身体各部位筋厚 & 大腿前部 $(\mathrm{mm})$ & $27.1 \pm 7.6$ & $18.1 \pm 5.6$ & $<0.000$ \\
$(\mathrm{~mm})$ & 大腿後部 $(\mathrm{mm})$ & $41.4 \pm 6.9$ & $38.9 \pm 7.1$ & 0.188 \\
& 下腿前部 $(\mathrm{mm})$ & $26.6 \pm 2.7$ & $22.3 \pm 0.0$ & $<0.000$ \\
& 下腿後部 $(\mathrm{mm})$ & $44.6 \pm 7.1$ & $40.5 \pm 6.8$ & 0.093 \\
\hline & 上腕前部 $\left(\mathrm{mm} / \mathrm{kg}^{1 / 3}\right)$ & $6.9 \pm 0.9$ & $5.2 \pm 1.1$ & $<0.000$ \\
& 上腕後部 $\left(\mathrm{mm} / \mathrm{kg}^{1 / 3}\right)$ & $4.6 \pm 1.3$ & $3.6 \pm 1.0$ & $<0.018$ \\
身体各部位筋厚補正值 & 大腿前部 $\left(\mathrm{mm} / \mathrm{kg}^{1 / 3}\right)$ & $6.7 \pm 1.6$ & $4.7 \pm 1.4$ & $<0.000$ \\
$\left(\mathrm{~mm} / \mathrm{kg}^{1 / 3}\right)$ & 大腿後部 $\left(\mathrm{mm} / \mathrm{kg}^{1 / 3}\right)$ & $10.4 \pm 1.6$ & $10.3 \pm 2.0$ & 0.710 \\
& 下腿前部 $\left(\mathrm{mm} / \mathrm{kg}^{1 / 3}\right)$ & $6.7 \pm 0.6$ & $5.9 \pm 1.0$ & $<0.004$ \\
& 下腿後部 $\left(\mathrm{mm} / \mathrm{kg}^{1 / 3}\right)$ & $11.2 \pm 1.7$ & $10.7 \pm 2.2$ & 0.481 \\
\hline
\end{tabular}

男女高齢者を対象とした渡辺ら ${ }^{18)}$ の研究では，男性は 女性よりも閉じこもり率が有意に高いことが示唆され ている。また，全国の大規模データを用いて健常な地 域在住高齢者における外出行動や社会的・余暇活動の 性差を調査した斎藤ら ${ }^{19)}$ の研究においては, 男性が女 性よりも団体・会への参加や友人 · 知人との交流が少 ないことを報告している。このように，男性高齢者で は地域での活動参加や他者交流の頻度が減少し, 閉じ こもりになることが考えられ, 本研究でも先行研究 ${ }^{18,19}$ を支持する結果となった。
男性高齢者群に比べて女性高齢者群では大腿前部, 上腕前部および後部，下腿前部の筋厚補正值に有意な 低值を認めた。それらの筋厚補正值は大腿前部（一 $29.9 \%)$, 上腕前部 $(-25.4 \%)$, 上腕後部 $(-22.5 \%)$, 下腿前部 $(-11.8 \%)$ の順に性差が大きいことが示さ れた。20歳代から70および80歳代の男女を対象とした 福元ら ${ }^{20)}$ の研究によると, 男性では女性と比べて膝関 節伸筋群横断面積の值が高值を示しており, その性差 は下肢筋群のなかでも最も大きいことを報告している。 さらに，男女別にそれぞれ上下肢の各部位筋力を調査 
した Bohannon ら ${ }^{211}$ の研究では, 高齢期の膝伸展筋力 は性差が大きい。筋厚は筋力との関係が深く, 特に大 腿前部の筋厚と膝伸展筋力には強い正の相関が認めら れている222。これらのことから，高齢期では大腿前部 の筋厚補正值は各部位のなかでも性差が大きいことが 考えられる。

上腕前部および後部の筋厚補正值では大腿前部に比 べて性差は小さかった。成人を対象とした金久 ${ }^{23}$ の報 告に扔いては，身体各部位筋厚の性差は下肢よりも上 肢に大きく表れることを示唆している。しかしながら， 本研究では要支援・要介護高齢者を対象としており, 上腕部の筋厚補正值は大腿前部の筋厚補正值よりも性 差が小さく, 前述の先行研究23) と一致しなかった。

男性高齢者群では女性高齢者群と比べて下腿前部の 筋厚補正值に有意な高值を認めたが，大腿前部および 上腕前・後部に比べると性差は小さい。70歳代の男女 高齢者を対象とした宮谷ら ${ }^{17)}$ の研究によると, 男性で は女性に比べて各部位の筋厚補正值は有意に高値を示 しており，下腿前部（-1.4\%）においては大腿前部 (-11.5\%) に比べて性差が小さい。さらに，70歳代 の男女高齢者を対象とした Bohannon ら ${ }^{21}$ の研究にお いて, 男性は女性に比べて各部位の筋力が有意に高值 を示しているが, 足背屈筋力 $(-9.3 \%)$ では膝伸展 筋力 $(-23.3 \%)$ よりも性差は小さい。これらのこと から, 要支援・要介護高齢者の下腿前部の筋厚補正值 では, 大腿前部および上腕部の筋厚補正值よりも性差 は小さいことが推察される。

一方, 本研究では男性高齢者群と女性高齢者群の間 で大腿後部および下腿後部の筋厚補正值に有意な差を 認めなかった。70歳代の男女高齢者を対象とした宮谷 $ら^{17)}$ の研究では, 身体各部位の大腿後部および下腿後 部の筋厚補正值に性差は認めなかったことが報告され ている。このように，身体各部位筋厚のなかでも大腿 後部および下腿後部の筋厚補正值は性差の影響を受け にくいことが示唆されており, 本研究の結果とも一致 した。

本研究では, 地域在住要支援・要介護高齢者におけ る男女間の身体各部位筋厚とフレイルの 3 側面の性差 を検証した。その結果, 男性高齢者群では女性高齢者 群に比べて大腿前部，上腕前部および後部，下腿前部 の筋厚補正值は有意に高值を認めたが，大腿後部およ び下腿後部の筋厚補正值に有意な差は認められなかっ た。さらに, 男性高齢者群では, 女性高齢者群と比べ て閉じこもりの傾向が高いことが示唆された。これま
での介護予防では，性差に応じた身体各部位筋厚とフ レイルへの対策はされていない。本研究の結果から, 要支援・要介護高齢者では性別に応じた介護予防方法 の提案が期待される。

本研究の限界として, 対象となった要支援・要介護 高齢者群は通所サービスおよび訪問リハビリでのリハ ビリを行っている者である。したがって，要支援・要 介護高齢者群の対象者におけるリハビリの介入が身体 各部位の筋厚補正值に一部影響を及ぼしている可能性 がある。今後はリハビリでの運動強度や頻度などにも 着目しながら，身体各部位筋厚との関連性を検討して いきたい。

\section{利益相反}

本研究に関して，開示すべき利益相反はない。

\section{引用文献}

1)内閣府：令和元年度版度版高齢社会白書（概要版）高齢化 の状況. 東京, 2019, 2 - 6 .

2)鈴木隆雄 : 介護予防とフレイルー科学的根拠に基づく健康 維持と予防対策一。アンチ・エイジング医学, 2016, 12 (5) : 607-612.

3) Kojima G, Iliffe S, Taniguchi Y, et al.: Prevalence of frailty in Japan: A systematic review and meta-analysis. J Epidemiol. 2017, 27 (8): 347-353.

4) Xue QL, Bandeen-Roche K, Varadhan R, et al.: Initial manifestations of frailty criteria and the development of frailty phenotype in the Women's Health and Aging Study II. J Gerontol A Biol Sci Med Sci, 2008, 63 (9): 984-990.

5) Fried LP, Tangen CM, Walston J, et al.: Frailty in older adults: evidence for a phenotype. J Gerontol A Biol Sci Med Sci, 2001, 56 (3): M 146-156.

6)一般社団法人日本老年医学会ホームページ フレイルに関 する日本老年医学会からのステートメント. http://www.jpn-geriat-soc.or.jp/info/topics/pdf/2014513_01 _01.pdf（2021年 3 月20日引用）

7) 山田陽介, 山縣恵美, 木村みさか：フレイルティ\&サルコ ペニアと介護予防。京府医大誌，2012，121(10)：535-547.

8) Abe T, Sakamaki M, Yasuda T, et al.: Age-related, sitespecific muscle loss in 1507 Japanese men and women aged 20 to 95 years. J Sports Sci Med. 2011, 10(1): 145-150.

9) Nijholt W, Scafoglieri A, Jager-Wittenaar H, et al. : The reliability and validity of ultrasound to quantify muscles in older adults: a systematic review. J Cachexia Sarcopenia Muscle. 2017, 8 (5): 702-712.

10) Miyatani M, Kanehisa H, Ito M, et al. : The accuracy of volume estimates using ultrasound muscle thickness measurements in different muscle groups. Eur J Appl Physiol. 2004, 91 (2-3): 264-272.

11) Abe T, Patterson KM, Stover CD, et al. : Site-specific thigh 
muscle loss as an independent phenomenon for age-related muscle loss in middle-aged and older men and women. AGE, 2014, 36 (3): 1353-1358.

12) Abe T, Loenneke JP, Young KC, et al. : Validity of ultrasound prediction equations for total and regional muscularity in middle-aged and older men and women. Ultrasound Med Biol, 2015, 41 (2): 557-564.

13) Ido A, Nakayama Y, Ishii K, et al. : Ultrasound-derived abdominal muscle thickness better detects metabolic syndrome risk in obese patients than skeletal muscle index measured by dual-energy X-ray absorptiometry. PLoS ONE, 2015, 10 (12): e0143858.

14) 基本チェックリストの考え方について（平成18年 3 月審査 分).

http://www.mhlw.go.jp/topics/2007/03/dl/tp0313-1a-11.pdf (2021年 3 月20日引用)

15) Sewo Sampaio PY, Sampaio RA, Yamada M, et al.: Systematic review of the Kihon Checklist: Is it a reliable assessment of frailty?. Geriatr Gerontol Int. 2016, 16 (8): 893-902.

16) 安部孝, 福永哲夫：日本人の体脂肪と筋肉分布. 杏林書院, 1995, 34-50.

17)宮谷昌枝, 東香寿美, 金久博昭 - 他 : 下肢筋厚に打ける加 齢変化の部位差および性差 -20 歳代と70歳代の比較一。体 力科学, 2003,52 (suppl) : 133-140.

18) 渡辺美鈴, 渡辺丈眞, 松浦尊麿 - 他 : 自立生活の在宅高齢 者の閉じこもりによる要介護の発生状況について. 日老医 誌, 2005, 42(1)：99-105.

19) 斎藤民, 近藤克則, 村田千代栄 - 他 : 高齢者の外出行動と · 余餟的活動における性差と地域差－JAGES プロジェクトか ら-。 日本公衛誌, 2015, 62(10)：596-608.

20) 福元清剛, 石内愛美, 中島弘貴 - 他 : 日本人男女の下肢筋 横断面積の加齢変化. 日本生理人類学会誌, 2018, 23(3)： 87-95.

21)Bohannon RW: Reference values for extremity muscle strength obtained by hand-held dynamometry from adults aged 20 to 79 years. Arch Phys Med Rehabil, 1997, 78(1) : 2632.

22)村木里志, 福田修, 福元清剛：筋の厚さ (量) と硬さ（質） から筋力を推定する方法の開発. 健康医科学研究助成論文 集, 2009, 24:126-133.

23) 金久博昭 : 筋量 ·筋力における性差. 体力科学, 2016, 65 (1) : 43 . 